\title{
CORRESPONDENCE
}

\section{International peer review improved Irish research rankings}

SIR - Your News story 'Italy outsources peer review to $\mathrm{NIH}^{\prime}$ (Nature 459, 900; 2009) highlights a problem common to many countries with a small population of research scientists. Ireland can be held up as a successful model in addressing this problem because, over the past eight years, funding agencies have moved to fully international peer review.

A few years ago, important research and development ventures were set up with a new infrastructure to attract talented people from abroad. The use of only Irish peer reviewers to allocate millions of research euros to a small number of universities could not stand up to the principles of objectivity, transparency and perceived fairness and would have led to conflicts of interest. Despite initial opposition, exclusively international review is now accepted; researchers want to be benchmarked internationally as well as nationally.

The typical process for research evaluation in Ireland is to consult four or five reviewers by mail for each proposal. Proposals are then assessed by a panel of invited experts, who meet in Ireland. Reviewers may be sourced through international funding agencies, or by letting applicants nominate experts themselves.

Some Italian scientists in your News story express reservations. They may well have a point, as US reviewers will probably not have any detailed knowledge of how research is conducted in Italy. One approach is to have nationals involved, either as observers or in a formal non-voting role. For example, the Irish Health Research Board (www.hrb.ie) organizes international mail reviews and panels, but the chair of each is Irish. They cannot participate in selection, but ensure that the correct procedures are followed and can explain the national research-funding policy. International panel members appreciate this local input, which helps them think outside their own national funding system.

Reviewing criteria often include the quality of the project, the researchers and their institutions, and the social and economic impact of the research. It is important that international reviewers focus on the quality of the first two, as the standing of institutions and the probable impact of a project can be harder for them to evaluate. Also, they should not get involved in detailed budgetary considerations, as these are strictly national.

Things have changed radically in Ireland's research over the past ten years. In 2008, the country appeared for the first time in a list of 'Top countries in all fields' (ranked by citations per paper; http://tinyurl.com/m5wdcl).

We are now placed 19th, up from 36th place in 2003. I believe that international peer review played a significant part in this development.

Conor O'Carroll Irish Universities Association, 48 Merrion Square, Dublin 2, Ireland

e-mail:conor.ocarroll@iua.ie

\section{Hispanic people start leaping over barriers to better jobs}

SIR - Earlier this month, Sonia Sotomayor was confirmed as a member of the US Supreme Court, the first judge of Puerto Rican descent to be appointed. It is an encouraging result for both women and Hispanic people in the United States. Could it be that the barriers are at last crumbling for Hispanic people trying to reach high-ranking positions?

In the United States, people of Hispanic origin are notably underrepresented in science, technology, engineering and mathematics, and high achievers are rare. Although the proportion of Hispanic students enrolling in post-secondary courses in science, technology, engineering and mathematics in 2001 was the same as that of white or black ethnic groups, only $16 \%$ completed a bachelor's degree in these fields, compared with nearly $30 \%$ of white students (see http://tinyurl.com/ms9kpr). This picture has barely changed: according to the US Department of Labor, by 2012 about $15 \%$ of all US jobs will be filled by Hispanic workers, but only $1 \%$ will be at executive level.

With Hispanic people and their descendants expected to reach $30 \%$ of the total US population by 2050 , closure of this gap comes none too soon.

Annelyn Torres-Reveron College of Pharmacy, Nova Southeastern University, 2250 Ave Las Americas, Ponce, 00717-9997, Puerto Rico e-mail: at583@nova.edu

\section{Whistleblowers at risk as science fails to correct itself}

SIR - In his review of my book about Jan Hendrik Schön's fraud at Bell Laboratories, Plastic Fantastic: How the Biggest Fraud in Physics Shook the Scientific World, Martin Blume argues that the vigilance of whistleblowers is part of the natural corrective process of science ('Keeping up scientific standards' Nature 459, 645-646; 2009). I disagree.

Blume's analysis fails to explain why whistleblowers so often find themselves working outside ordinary channels. In science today, the activities of searching for manipulated data, pursuing charges against colleagues and investigating others for misconduct are considered extra to normal scientific activity. Many suffer for speaking up, damaging their reputations. The fact that, in this rare case, the establishment did come around to the whistleblowers' position is not a reason to play down the risks they face, or the initiative and imagination needed to work around or take on reluctant scientific institutions.

Also, the correction of fraud often fails to happen through other recognized channels. Blume mentions the attempted replication of experiments by other laboratories and peer review, which were seriously wanting in the Schön case. Schön was only exposed when information about data irregularities previously noticed inside Bell Labs was passed along a chain of concerned scientists to independent external researchers. Whistleblowers only became involved after management failed to act effectively on internal concerns.

Science today can claim ownership of some corrective processes, including criticism of unrealistic research findings. Whistleblowing, sadly, is not among them.

Eugenie Samuel Reich Cambridge, Massachusetts 02139, USA e-mail: eugenie.reich@gmail.com

See also Correction on page 957

\section{South Dakota school replies to sexual harassment claims}

SIR - Your News story 'Sex scandal allegations surface at South Dakota school' (Nature 459, 148; 2009) questions how the South Dakota School of Mines and Technology "will handle human-resource issues under its ... subcontract for the Deep Underground Science and Engineering Laboratory" in the light of alleged issues of sexual harassment. Your implication is unfair.

Although the school and its employees cannot comment upon the reasons for personnel actions, as director of human resources I wish to emphasize that we have no knowledge of any unresolved complaints, nor have we been apprised of any current concerns of the type alleged in the article.

Deborah L. Sloat South Dakota School of Mines and Technology, 501 E. St Joseph Street, Rapid City, South Dakota 57701, USA e-mail:deborah.sloat@sdsmt.edu 